\title{
Antibacterial Activity of Marula [Sclerocarya Birrea] and Brominated Marula Seed Oil
}

\author{
J. S Ibrahim \\ Department of Chemistry, Abubakar \\ Tafawa Balewa University \\ (A.T.B.U) Bauchi Nigeria
}

\author{
H.M Adamu \\ Department of Chemistry, Abubakar \\ Tafawa Balewa University \\ (A.T.B.U) Bauchi Nigeria
}

\author{
O.I Shakede \\ Department of Chemistry, Abubakar \\ Tafawa Balewa University \\ (A.T.B.U) Bauchi Nigeria
}

Abstract:- Over the last decade, the use of hand sanitizers has increased substantially. Recently, with this outbreak of COVID 19 virus, all natural hand sanitizers have taken the spotlight for their simplicity, powerful cleaning abilities, natural moisturizing formulas and the ability to never leave the skin feeling dry. Marula [Sclerocarya birrea] seed oil was soxhlet extracted with n-hexane and then brominated. The oil quality parameters of marula oil (MO) and brominated Marula oil (BMO) were found to be; for MO: oil content $(58.5 \pm 0.435 \%)$, moisture content $(4.3 \pm 0.158$ $\%)$, saponification value $(180 \pm 0.7150 \mathrm{mgKOH} / \mathrm{g})$, peroxide value $(10.52 \pm 0.006 \mathrm{meq} / \mathrm{kg})$, acid value $(3.48$ $\pm 0.002) \mathrm{meq} / \mathrm{kg})$, FFA $(1.73 \pm \mathbf{0 . 0 0 0} \%$ as oleic $)$,iodine value $\left(61.02 \pm 0.477 \mathrm{gI}_{2} / 100 \mathrm{~g}\right)$. For brominated marula oil (BMO) ; saponification value ( $168.7 \pm 0.930$ $\mathrm{mgKOH} / \mathrm{g}$ ), iodine value ( $\left.8.6 \pm 0.490 \mathrm{gI}_{2} / 100 \mathrm{~g}\right)$, peroxide value $(10.63 \pm 0.505 \mathrm{meq} / \mathrm{kg})$, acid value $(3.42$ $\pm 0.000 \mathrm{meq} / \mathrm{kg})$, FFA $(1.61 \pm \mathbf{0 . 0 0 0} \%$ as oleic $)$. Fourier Transform Infrared (FTIR) spectroscopy was used to confirm the bromination process. The following peaks of absorptions were observed for BMO: $\mathrm{C}-\mathrm{Br}$ at 600 $\mathrm{cm}^{-1}, \mathrm{C}-\mathrm{H}$ stretch, (2950 to $2850 \mathrm{~cm}^{-1}$ for alkane), $1750 \mathrm{~cm}^{-1}$ for carbonyl stretch, $1450 \mathrm{~cm}^{-1}$ for ester, 1680 $\mathrm{cm}^{-1}$ for alkene. The BMO showed a broad spectrum activity against $E$. coli, Salmonella sp, Staphylococcus aureus and Streptococcus epidermidis microorganism which gave the inhibitions zones of $19.50 \mathrm{~mm}, 20.50$ $\mathrm{mm}, 19.00 \mathrm{~mm}, 18.60 \mathrm{~mm}$ respectively. DMSO was used as the negative control while streptomycin as the positive control at $400 \mathrm{mg} / \mathrm{ml}$ concentration. Based on these findings, BMO may be use as disinfecting oils or hand sanitizers and will discourage its use as food additive.

Keywords:- Brominated Marula oil, Infrared spectroscopy, Microorganism, and Inhibition zone.

\section{INTRODUCTION}

Brominated Vegetable Oils (BVO) are complex mixtures of plant derived triglycerides that have been reacted to contain atoms of the element bromine bonded to the molecules [12]. Brominated vegetable oil has extensively been used as a food additive in soft drink manufacture, where it has been used as an emulsifying agent. However, in other applications, it has been utilized for its fire retardant properties a practice that have brought to question in its continued use as a food additive [10]. This is arising from reported cases of Bromism [5] and the observed increase in the level of brominated fatty acids that have been noted to be stored away in the body's lipid [10,11]. To support this assertion is the reported effort of BVO on yeast population [7] and thus its possible effect on human body cells, a fact that have been pointed out in studies with experimental animals.

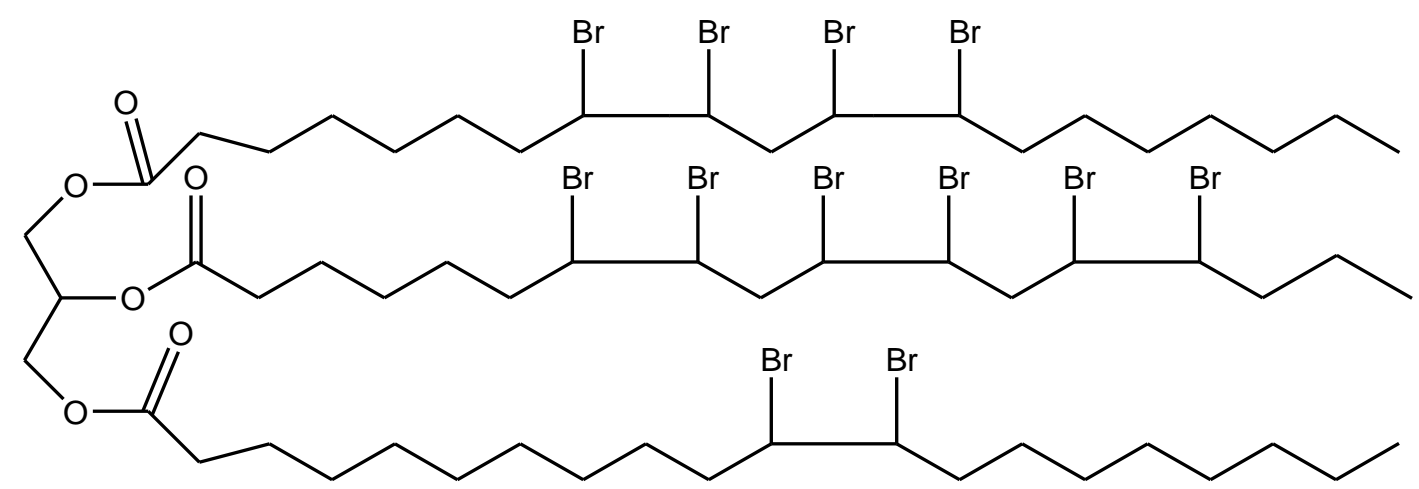

Fig 1:- Chemical structure of a representative constituent of BVO, featuring from the top, Brominated linoloate, linolenoate and oleate esters

\section{Marula (Sclerocarya birrea)}

Marula oil is extracted from the kernels (nuts) of the marula tree (Sclerocarya birrea), from the Anacardiaceous family. Marula oil is traditionally used in cosmetics, in food as cooking oil and as a meat preservative and to treat leather [4].
Marula oil contains a large proportion of monounsaturated fatty acids and natural antioxidants which makes the oil very stable. The fatty acid composition of Marula oil include; mono-unsaturated fatty acids: Oleic acid (70-78\%), polyunsaturated fatty acid: Linoleic acid 
(4.0-7.0 \%), saturated fatty acids: stearic (5.0-8.0\%), palmitic (9.0-12.0\%) and arachidonic acid (0.3-0.7\%).

\section{MATERIALS AND METHODS}

The kernel of plant Sclerocarya birrea was obtained within A T B U Bauchi metropolis. The sample was authenticated by the biological science department A.T.B.U Bauchi Nigeria.

The marula oil was soxhlet extracted using n-hexane and was brominated.The oil quality parameters of marula oil (MO) and brominated marula oil (BMO) was determined using a standard method by [1]. Infrared (Ir) spectroscopy was use to confirm the bromination process.

\section{Bromination process}

This involves direct bromine adding with a dropping funnel into the oil sample in a Erlenmeyer flask at a maintained temperature of not more than $50^{\circ} \mathrm{C}$. The reaction took up to 8 hours under vigorous strirring with magnetic stirrer with a condenser connected under a fume curpboad.

\section{Antibacterial Evaluation of $M O$ and $B M O$}

The Disc Diffusion Method for antimicrobial susceptibility testing was adopted $[6,9]$ to access the presence of the antibacterial activity of MO and BMO. Bacteria culture of E Coli, Salmonella species, Staphylococcus aureus and Streptococcus epidermidis were used. In this method discs which have been impregnated with $\mathrm{MO}$ and $\mathrm{BMO}$ was placed on the Muller-Hinton Agar (MHA) plate surface, with each test plate comprising of 6 discs. The plates were incubated at $37^{\circ} \mathrm{C}$ for 18 to 24 hours, after which the plates was examined for inhibition zones diameter was measured using calipers and were recorded. Controls were conducted in line with the above procedure, using streptomycin antibiotic for positive control while dimethylsulphoxide (DMSO) for negative control.

\section{Extract Preparation}

About $0.4 \mathrm{ml}$ of the extract (each of MO and BMO) were dissolved and made up to $1 \mathrm{ml}$ with DMSO to give a concentration of $400 \mathrm{mg} / \mathrm{ml}$ each.

\section{RESULTS AND DISCUSSION}

The moisture content of the Marula oil (4.3\%) was moderately high which could be responsible for the hydrolysis of triglycerides to yield high level of free fatty acids and will lead to high refining losses of oil yield $(58.5 \%)$ as consequences as shown in table 1. Other parameters which include; acid value (AV), perioxide value (PV), saponification value (SV), free fatty acid (FFA), and iodine value (IV) were also presented at table 1 . The results of MO and BMO were very close but differs only in their IV which was due to the addition of bromine across the double bond positions in the fatty acids triglyceride (MO; $61.02 \mathrm{gI}_{2} / 100 \mathrm{~g}$ and BMO; $8.6 \mathrm{gI}_{2} / 100 \mathrm{~g}$ )

As shown in the table below

\begin{tabular}{|c|c|c|c|}
\hline S/N & Oil Quality Parameters & MO & BMO \\
\hline $\mathbf{1}$ & FFA(\% as oleic) & $1.73 \pm 0.000$ & $1.61 \pm 0.000$ \\
\hline $\mathbf{2}$ & AV(meq/kg) & $3,48 \pm 0.002$ & $3.42 \pm 0.000$ \\
\hline $\mathbf{3}$ & PV(meq/kg) & $10.52 \pm 0.006$ & $10.63 \pm 0.505$ \\
\hline $\mathbf{4}$ & IV(gI $/ 100 \mathrm{~g})$ & $61.02 \pm 0.477$ & $16.6 \pm 0.490$ \\
\hline $\mathbf{5}$ & $\mathrm{SV}(\mathrm{mgKOH} / \mathrm{g})$ & $180 \pm 0.7150$ & \\
\hline $\mathbf{6}$ & Moisture content $(\%)$ & $4.3 \pm 0.158$ & \\
\hline $\mathbf{7}$ & Oil Content $(\%)$ & $58.5 \pm 0.435$ & \\
\hline
\end{tabular}

Table 1:- Oil quality parameters of /MO and BMO

The results are express in terms of mean \pm standard deviation)

Iodine value (IV) is the measure of the overall unsaturation in the structural matrix of the oil and it is usually used to characterize oils and fats as nondrying, semi drying and drying. However, the IV of MO and BMO falls within the nondrying class. The reduction of IV in BMO $\left(8.6 \mathrm{gI}_{2} / 100 \mathrm{~g}\right)$ from $\left(61.02 \mathrm{gI}_{2} / 100 \mathrm{~g}\right)$ for MO (table 1.) indicate that bromination has occurred but not $100 \%$ completion.

Evidence that bromination has occurred, is the sharp weak absorption of carbon-bromine bond at $600 \mathrm{~cm}^{-1}$ at table 3 . And its absence in that of MO at table 2. Presence of some targeted functional groups like the carbonyl stretch $1750 \mathrm{~cm}^{-1}, 1400 \mathrm{~cm}^{-1}$ for C$\mathrm{O}$ ester and 1660 to $1680 \mathrm{~cm}^{-1}$ for $\mathrm{C}=\mathrm{C}$ alkene were observed in both IR spectra of MO and BMO (table 2\&3). 
ISSN No:-2456-2165

\begin{tabular}{|c|c|l|l|}
\hline Sample & $\begin{array}{c}\text { Absorption } \\
\text { Frequency }\left(\mathbf{c m}^{-1}\right)\end{array}$ & Types of Bond & Remark \\
\hline Marula Oil & 3050 & C-H Stretching & Alkene \\
\hline & 2950 & C-H Stretching & $\mathrm{CH}_{3}$-and- $\mathrm{CH}_{2}$ - \\
\hline & 2800 & C-H Stretching & -CH- \\
\hline & 1750 & $-\mathrm{C}=\mathrm{O}$ Stretching & Carbonyl \\
\hline & 1660 & $\begin{array}{c}\text {-C=C } \\
\text { Stretching }\end{array}$ & Alkene \\
\hline & 1450 & C-O- Stretching & Ester \\
\hline
\end{tabular}

Table 2:- FTIR Spectra Interpretation of Marula oil (MO)

TITLE: J_I_S_C

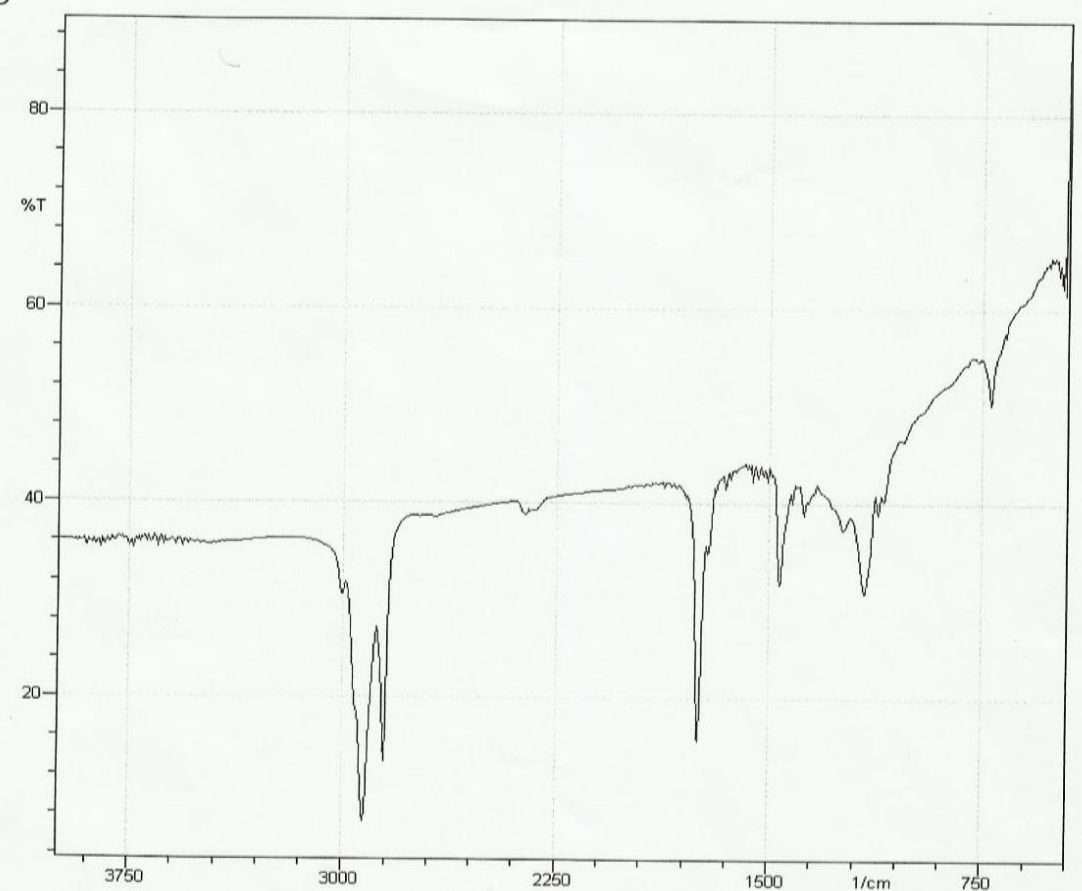

Labels of J_I_S_C:

Fig 2:- I.R data sheet of Marula oi

\begin{tabular}{|c|c|l|l|}
\hline Sample & $\begin{array}{c}\text { Absorption } \\
\left.\text { Frequency } \mathbf{( c m}^{-1}\right)\end{array}$ & Types of Bond & Remark \\
\hline $\begin{array}{c}\text { Brominated } \\
\text { Marula Oil }\end{array}$ & 2950 & C-H Stretching & $\begin{array}{l}\mathrm{CH}_{3^{-}} \text {and } \\
-\mathrm{CH}_{2-}^{-}\end{array}$ \\
\hline & 2850 & C-H Stretching & $-\mathrm{CH}^{-}$ \\
\hline & 1750 & $\begin{array}{l}\mathrm{C}=\mathrm{O} \\
\text { Stretching }\end{array}$ & Carbonyl \\
\hline & 1450 & $\begin{array}{l}\mathrm{C}-\mathrm{O}- \\
\text { Stretching }\end{array}$ & Ester \\
\hline & 1680 & $\begin{array}{l}-\mathrm{C}=\mathrm{C} \\
\text { Stretching }\end{array}$ & Alkene \\
\hline & 600 & C-Br Stretching & C-Br Bond \\
\hline
\end{tabular}

Table 3:- IR Spectra Interpretation of Brominated Marula Oil (BMO) 


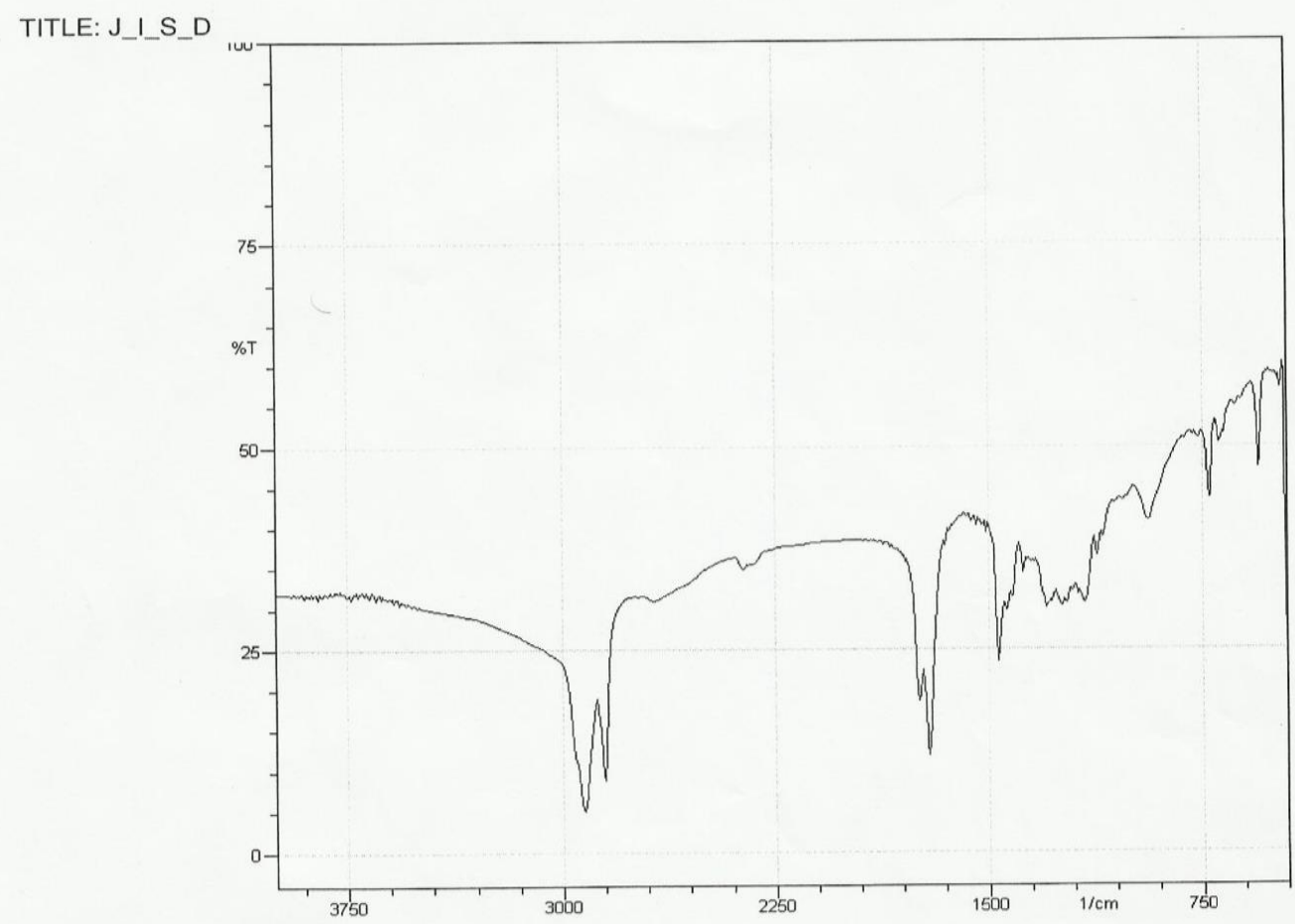

Labels of J_I_S_D:

Fig 3:- I.R data sheet of Brominated Marula Oil.

BMO showed a broad activity against E coli, salmonella $\mathrm{sp}$, staphylococcus aureus and streptococcus epidermidis microorganism which gave the inhibition zones of $17 \mathrm{~mm}, 16.5 \mathrm{~mm}, 15 \mathrm{~mm}$ and $16.0 \mathrm{~mm}$ respectively. Dimethylsulphoxide (DMSO) was used as the negative control while Streptomycin as the positive control at $400 \mathrm{mg} / \mathrm{ml}$ sample concentration.

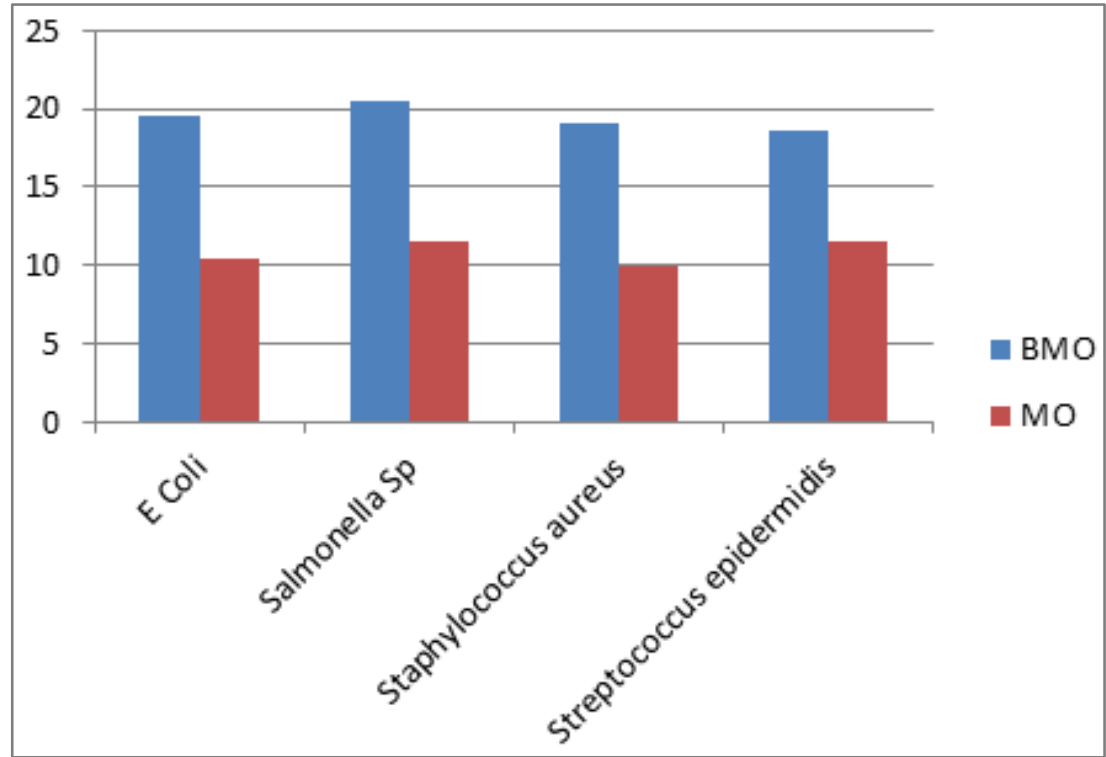

Fig 4:- A plot of bacteria against inhibition zones (in $\mathrm{mm}$ )

\section{CONCLUSION}

This research work was successful since marula oil was extracted and brominated. The oil quality parameters of the marula oil and its brominated derivative was determined. The IR spectroscopy of MO and BMO were conducted to verify the presence of some targeted functional groups and to confirm the bromination process.
Antibacterial activity of the two (MO and BMO) shows activity with microbes that was used.

Focusing on the activity BMO has on some bacteria, a suggestion of it as an antimicrobial agent, can be explored and exploited for it application as sanitary products such as hand sanitizers or as disinfecting oils. 


\section{REFERENCES}

[1]. Abayeh, O.J and Shekarau, J.I. (2010) Transesterified water melon (Citrillus Vulgarus) seed oil as a biodiesel fuel.Journal Chemical Society of Nigeria.35(1):38-42

[2]. Corn Refiners Association (2006) "Corn oil"5th Edition. p.20. www.corn.org.

[3]. Erdemir, S.M (2013)"The best disinfecting Essential Oil".

www.livestrong.com/article/128508_disinfecting_esse ntial_oil/\#page $=1$

[4]. Hore,D. (2004). Formulation of Cosmetic Skin Lotions using Adansonia Digitata and Sclerocarya birrea oil from Zimbabwe, Harare. Patent US 2009/02858 A1. (spaassociationofafrica.com/wpcontent/upload.)

[5]. Horowitz, B(1997) "Bromism from excessive cola consumption". Journal of Toxicology and Clinical Toxicology35(3):15-320

[6]. Ladjel, S; Gherraf, N; Zellagui, A; Brahim, L and Hameurlaine, S. (2011) "Phytochemical and Antibacterial screening of some Algerian Saharan medicinal plants"Plant Science Feed.1(10):169-178.

[7]. Patel, B.H. (2012) "The effect of Brominated Vegetable Oil in yeast populations. California State Science Fair. 35, 66-71.

[8]. Rajendran, R.A; Singh, N; Mahajan, V; Chaudhary, D.P; Sapna and Kumar R.S. (2012). "Corn Oil: An Emerging Industrial Product”. Technical Bulletin 8; Directorate of Maize Research, India. 233p.

[9]. Urgras, T.H, Basaran, I; Kilic, T and Cakir, U (2006) "Synthesis, Complexation and Antifungal, Antibacterial Activity study of a new Macrocyclic Schiff base"J. Heterocyclic Chem. 43,1679.

[10]. Vetter, W; Maier, L and Bendig, P.(2010) "The Polybrominated flame retardants used in our children's soft drinks"Organohalogen Compounds 72:1169-1172.

[11]. Yeun, C (2014)"Prohibiting the use of Brominated Vegetable Oils"A Repo sssssby the Global Agricultural Network. http//www.accessdata.fda.gov/script/cdrh. 26/08/14

[12]. Zheng, C. (2014), "Brominated Vegetable Oil". Dietetic Intern. www.cyberlipid.org/fa/acid 0001.htm accessed on $23^{\text {rd }}$ September, 2014. 